(C) 1988 ISIJ

$$
\begin{aligned}
& \text { オーステナイト系ステンレス鋼の低サイクル } \\
& \text { 疲労軟化に及ぼす炭素の影響 }
\end{aligned}
$$

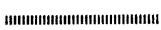
論 文

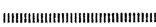

$$
\text { 柴田浩司 } * \text {. 小北雅彦 }{ }^{* 2} \cdot \text { 陳 成澍 } * 3 \cdot \text { 藤田利夫 }{ }^{*}
$$

\title{
The Effects of Carbon on Low Cycle Fatigue Softening of Austenitic Stainless Steels
}

Koji ShiBata, Masahiko Kogita, Cheng-shu Chen and Toshio Fujita

Synopsis :

Effects of carbon on low cycle fatigue behavior of $20 \mathrm{Cr}-15 \mathrm{Ni}$ and $15 \mathrm{Cr}-15 \mathrm{Ni}$ stainless steels have been investigated at room temperature. Thin foils from the cyclically deformed specimens were subjected to electron microscopy. Single crystals produced by remelting some of the steels were also tested. They were deformed by compression sliced in the predetermined directions, and their dislocation configurations were observed in electron microscope. The effects of carbon and/or silicon addition on proof strength, cyclic deformation behavior and dislocation configurations were also studied. It was shown that the carbon alloyed steels showed fatigue softening as reported previously in a $0.18 \mathrm{C}-25 \mathrm{Cr}-20 \mathrm{Ni}$ steel. The softening was observed even at the small number of cycles, and was enhanced by an increase in carbon content and a decrease in strain amplitude. Carbon also reduced the trend of dislocations to form cellular configurations. It was revealed that such effects of carbon were increased by $\mathrm{Si}$ addition and that $\mathrm{Si}$ increased the solid solution hardening by carbon. All these results were qualitatively consist with the concept that solid solution hardening by some complexes between carbon and chromium atoms existed in the as-solution treated condition and broke down during cyclic deformation to induce fatigue softening.

Key words : stainless steel ; fatigue ; softening ; carbon, silicon ; solid solution ; strength ; microscopy.

\section{1. 緒} 言

極低温用オーステナイト $(\gamma)$ 系鋼の強度を上げるの に N，Cの添加が有効であることが知られている11. し かし著者らは各種ステンレス鋼, 高マンガン鋼において $\mathrm{N}$ を添加すると低サイクル疲労試験時に著しい軟化が生 じることを明らかにした2゙ー5). C添加の効果についてみ ると研究例が少なく, 著者らにより, Cを $0.18 \%$ 添加 した SUS 310 系 $(25 \mathrm{Cr}-20 \mathrm{Ni})$ 鋼において溶体化処理 を十分行うと $\mathrm{N}$ 添加の場合ほど顕著ではないが疲労軟化 が生じること, 高マンガン鋼においてはマンガン量によ つて疲労軟化が生じないものもあるが, $18 \% \mathrm{Mn}$ 付近 では大きな疲労軟化が生じることが見出されている2)3) 程度である．また著者らもC添加の効果については N添 加の効果ほど詳しい観察を行つておらず, 同じステンレ ス鋼でも $\mathrm{Cr}$ 量, $\mathrm{Ni}$ 量, $\mathrm{C}$ 量あるいは歪み振幅の影響 などについては調べていない.この疲労軟化は, 高強度
極低温用鋼を使用するうえで無視できない現象であるば かりでなく，現在においても不明の点の多い677) $\mathrm{C}, \mathrm{N}$ による固溶強化機構に関する知見を与えるものであると も考えられる4). そこで本研究においては，20 Cr-15 Ni 系および $15 \mathrm{Cr}-15 \mathrm{Ni}$ 系ステンレス鋼を用い室温におけ る低サイクル疲労挙動に及ぼす Cの影響について観察す るとともに, 疲労軟化機構に関する検討を行つた。

\section{2. 実 験 方 法}

供試鋼の化学組成を Table 1 に示す. A シリーズは

Table 1. Chemical composition of steels (wt \%).

\begin{tabular}{c|cccccc}
\hline Steels & $\mathrm{C}$ & $\mathrm{Mn}$ & $\mathrm{Si}$ & $\mathrm{Ni}$ & $\mathrm{Cr}$ & $\mathrm{N}$ \\
\hline $\mathrm{A}-1$ & 0.01 & 1.00 & 0.77 & 15.21 & 19.84 & 0.0061 \\
$\mathrm{~A}-2$ & 0.20 & 1.53 & 0.80 & 15.67 & 20.19 & 0.0056 \\
$\mathrm{~A}-3$ & 0.29 & 1.50 & 1.80 & 15.42 & 19.47 & 0.0048 \\
$\mathrm{~B}-1$ & 0.006 & 1.55 & 0.01 & 15.02 & 15.13 & 0.0040 \\
$\mathrm{~B}-2$ & 0.005 & 1.50 & 1.85 & 15.30 & 15.61 & 0.0025 \\
$\mathrm{~B}-3$ & 0.27 & 1.48 & 0.06 & 15.11 & 15.30 & 0.0037 \\
$\mathrm{~B}-4$ & 0.30 & 1.49 & 1.97 & 15.27 & 15.27 & 0.0023 \\
\hline
\end{tabular}

$\mathrm{P}: \sim 0.003, \quad \mathrm{~S}: \sim 0.007$

昭和 61 年 4 月本会講演大会にて発表 昭和 62 年 3 月 5 日受付 (Received Mar. 5,1987 )

* 東京大学工学部 工博 (Faculty of Engineering, The University of Tokyo, 7-3-1 Hongo Bunkyo-ku, Tokyo 113)

*2 東京大学大学院 (現：(株)神戸製鋼所) (Graduate School, The University of Tokyo, Now Kobe Steel, Ltd.)

*3 東京大学研究生 (現: 中国西南交通大学) (Foreign Research Student, The University of Tokyo, Now Xi Nan Jiao Tong University) 
$20 \mathrm{Cr}-15 \mathrm{Ni}$ 系鋼で， C 量の影響を見るために用意した. Bシリーズは $15 \mathrm{Cr}-15 \mathrm{Ni}$ 系鋼で, 疲労軟化機構に関す る知見を得るため $\mathrm{C}$ の効果に加え $\mathrm{Si}$ の効果を調べる目 的で用意した。いずれも室温加工ではマルテンサイトを 誘起しないオーステナイト鋼であり, 高純度の原料を用 い真空誘導炉にて溶解した。熱間鍛造, 熱間圧延により $15 \mathrm{~mm}$ 厚の板にした後, 十分にCを固溶させるため $1300^{\circ} \mathrm{C} 1 \mathrm{~h}$ （水冷）の溶体化処理を行つた. 溶体化処理 後平行部直径 $5 \mathrm{~mm}$, 長さ $10 \mathrm{~mm}$ の試験片に加工しクロ ム酸りん酸溶液で表面を電解研磨してから室温での引張 試験, 疲労試験に供した。引張試験, 疲労試験はインス トロン型試験機を用い, 平行部の長さ変化をクリップ ゲージにて検出した5). 歪み速度はいずれもおよそ 3.0 $\times 10^{-3} \mathrm{~s}^{-1}$ とした，疲労試験においては, 完全両振り 全歪み振幅一定試験, 塑性歪み一定試験を行つて繰返し 数に対する応力振幅の変化を観察した. 全歪み一定試験 時の荷重方向の反転は試験機に付属している自動装置を 用いたが, 塑性歪み振幅一定試験時の荷重の反転は上記 自動装置の設定值を手動により頻繁に調整することによ り行つた，適当な繰返し数まで試験した試験片の平行部 より薄片を軸方向に直角に切り出し，透過電子顕微鏡に て転位配列の観察を行つた。電解研磨は, 過塩素酸 10

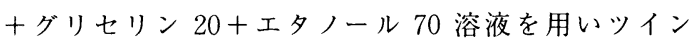
ジェット法にて行つた．疲労材の転位配列の電子顕微鏡 観察は，このような多結晶材を用いて数多く行い組織の 平均的な特徵をとらえようとした。また，荷重付加方向 抢よび薄膜の切り出し方向を決めて加工材の転位配列を 観察するため, A-1， A-3 鋼よりブリッジマン法にて単 結晶を作製し， $2 \%$ の圧縮变形後の転位配列の観察も行 つた．この場合荷重付加方向はく100>とし，この方位 と抢よそ $54^{\circ}$ の角度をなす $\{111\}$ 面に平行に薄膜を切 り出し, 電子顕微鏡観察した。 その際, X線ラウエ法に より方位の決定を行つたが，エッチング法8)にて方向性 ピット ${ }^{9}$ を単結晶表面に生じさせ, 切り出し方向決定の 補助手段とした.

\section{3. 実験結果および考察}

\section{$3 \cdot 1 \mathrm{~A}$ シリーズ $(20 \mathrm{Cr}-15 \mathrm{Ni}$ 系) 鋼の低サイクル疲労 挙動に及ぼす $\mathrm{C}$ 量と歪み振幅の影響}

Fig. 1 に全歪み振幅一定低サイクル疲労試験結果を 示す。全歪み振幅が $5.0 \times 10^{-3}$ の場合，疲労軟化（歪 み振幅一定試験を行つた場合応力振幅の減少）は A-1 鋼においては観察されず，A-2, A-3 鋼と C 量が增すに つれ初期疲労硬化後大きな軟化が観察されるようにな る. しかし A-2 鋼も全歪み振幅が $1.0 \times 10^{-2}$ と大きく
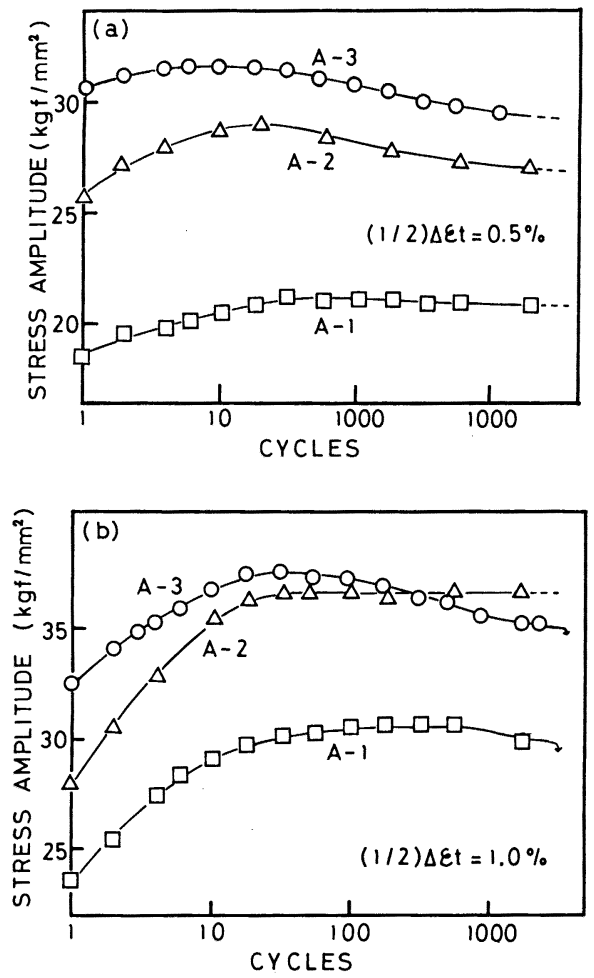

Fig. 1. Stress amplitude response in constant total strain amplitude tests of the A-series steels. The values of constant strain amplitude are (a) 5.0 $\times 10^{-3}$ and (b) $1.0 \times 10^{-2}$.

なると応力振幅は初期硬化の後減少せずほぼ一定の值と なる、A-3 鋼では全歪み振幅が $1.0 \times 10^{-2}$ の場合でも 疲労軟化が観察される。このように, 疲労軟化の程度は, $\mathrm{C}$ 量が多く歪み振幅が小さいほど大きい，また疲労軟化 はかなり少ない繰返し数より生じる。こうした疲労軟化 挙動は $\mathrm{N}$ を添加した各種ステンレス鋼や高マンガン鋼に おいて観察される ${ }^{2) ~}$ 疲労軟化の特徴と良く似ている. ただし、 $\mathrm{A}-2$ 鋼の $\mathrm{C}$ 量と同程度の $\mathrm{N}$ を添加したステン レス鋼において，全歪み振幅が $1.0 \times 10^{-2}$ でも疲労軟 化が見られる2)ことから，C添加の影響はN 添加の影響 より小さいことが推察される。つきに疲労変形材の転位 配列を詳細に観察したそその結果，Nを添加した各種ス

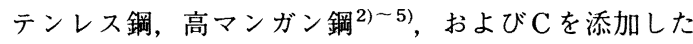
SUS 310 系鋼 23 ) 同様， A-2，A-3 鋼と C 量が増すに従 い平面状の転位配列が形成される傾向が強まることが分

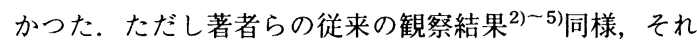
は疲労軟化が生じている場合に限り, 歪み振幅が大きく なつて軟化が認められなくなると転位はほとんどセル状 配列になる. Photo. 1 に，それぞれ A-1，A-3 鋼を全 


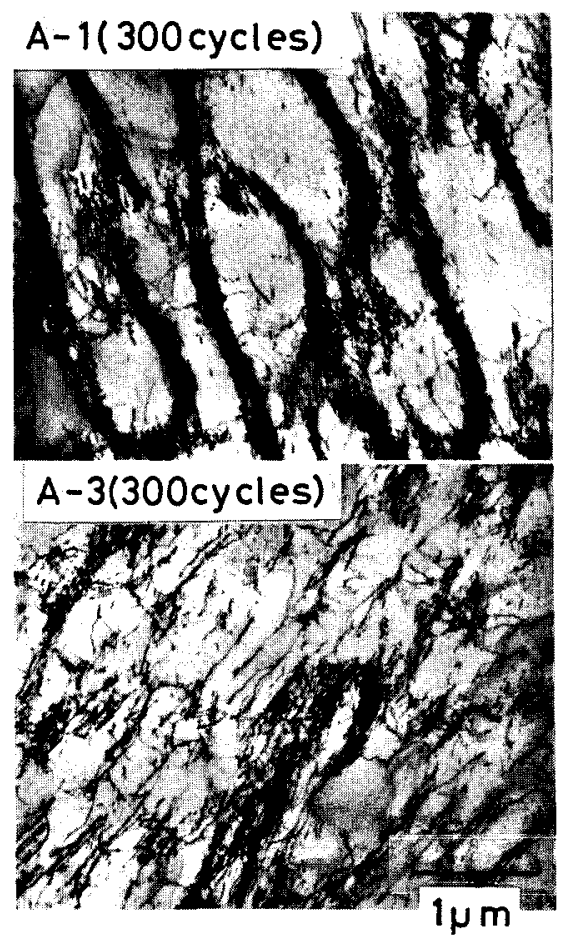

Photo. 1. Dislocation configurations of the steel A-1 and A-3 cyclically deformed under the constant total strain amplitude of $1.0 \times 10^{-2}$.

歪み振幅 $1.0 \times 10^{-2}$ で 300 回まで絽返し変形した場合 の代表的な電子顕微鏡組織を示す。

一方, 疲労材の転位配列は, 観察面が応力の付加方向 に対してどのような関係にあるかによって異なることが 考えられる10)。そのため上に述べた電子顕微鏡観察結 果は，観察例を多くして代表的な転位組織を比較したも のである. しかし, 従来, 荷重付加方向および薄膜の切 ク出し方向をそろえたうえで，加工材の転位配列を調べ た例は少ない，そこで次に単結晶を用いて，圧縮変形材 の転位配列の観察を行つた，単結晶試験片のC量は， $\mathrm{A}-1$ 鋼より作成したもの $0.0046 \%, \mathrm{~A}-3$ 龬より作成し たもの $0.253 \%$ であった，压縮軸方向はほほ したので，その方向と抢よそ $54^{\circ}$ の角度をなす四っの \{111\} 面で等価なすべりが生じることになる、薄膜はこ れらのうちの一つの $\{111\}$ 面に平行に切り出した。

Photo. 2 に観察䊅果の一例を示す. 電子ビームは膜面 である $\{111\}$ 面にほほ垂直である。このように A-3 鋼 中の転位に比べ A-1 鋼中の転位はもつれ合つており， C 添加材中の転位が交差すべりしにくい様子が観察され た.
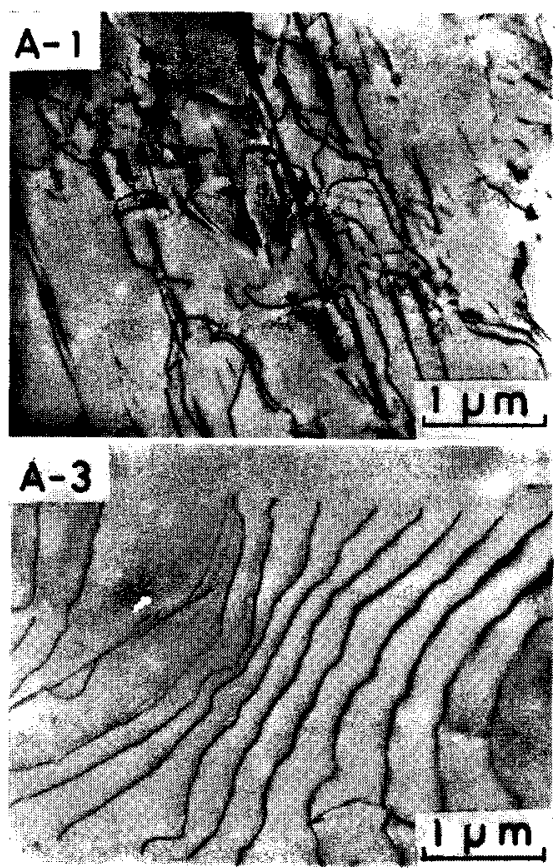

Photo. 2. Comparison of dislocation configurations using single crystals produced by remelting the $A-1$ and A-3 steels. Crystals were deformed by compression in $\langle 100\rangle$ direction and foils were sliced to be parallel to $\{111\}$ plane.

変形材の転位配列は一般に s.f.e.が低いほど平面状 になるとされている．従来オーステナイト系ステンレス 鋼の積層欠陥エネルギー（s.f.e.）は，C添加によつて わずか上がる ${ }^{1112)}$ か変化しない13)といわれている，従 つて, 著者らによるC 添加材の組織観察結果は, s. f.e. におよはす Cの影瑤に関する従来の報告が間違つている か, s.f.e. 以外に転位の交差すべりの頻度を左右するも のが存在することを示すことになる．前者の可能性に関 してみると，従来のデー夕は現在最も確からしいs.f.e. の測定法と言われている ${ }^{14) 15}$ 弱ビーム法を用いた電子 顕微鏡観察によるものではない，またC 原子と積層欠宿 との相互作用 ${ }^{16)}$ を分考虑して求められたものでもな い.すなわちオーステナイト系ステンレス鋼のs.f.e. におよはすのの影響に関する従来の報告は再検討する必 要があるものと考えられる，後者に関しては，IS 結合 体の可能性が考えられる. IS 結合体とは, 溶体化处理 状態ですでに存在していると考えられる Crあるいは $\mathrm{Mn}$ と CあるいはNの間で吸引相互作用に起因する結合

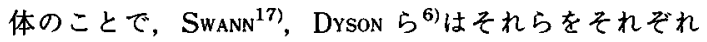
短範囲規則格子，クラスターリングと呼んでいる。また 
そうした結合体の存在は熱力学的にも予想されてい

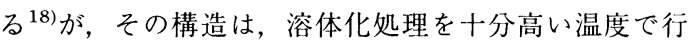
つているのであまり複雑ではないと考えられるものの, 具体的には明らかではない，そのため, 著者らはそのよ うな結合体を, 溶体化処理状態で存在する侵入型固溶原 子（I）と置換型固溶原子（S）との間の何らかの結合 体と言う意味で，とりあえず IS 結合体と呼ぶことにし た ${ }^{4)}$. $\mathrm{N}$ 添加鋼においては, 平面状の転位配列の形成傾 向が必ずしも s.f.e.の高低と対応しないことが以前よ り指摘されているが, SWANN ${ }^{17)}$, Douglassら ${ }^{199}$ はこれを IS 結合体の存在から説明している.N添加鋼において IS 結合体が存在するとすれば，上に述べたように，本 研究において C 添加の効果は程度の差はあるものの $\mathrm{N}$ 添 加の効果とよく似ていることを示寸結果が得られたこと から，C添加鋼に扔いても IS 結合体が存在することが 類推される．そのように考えるとオーステナイト鋼にお いて C 添加による固溶強化よりも N添加による固溶強化 のほうがかなり大き( ${ }^{144) 7}$ こと, $\mathrm{C}, \mathrm{N}$ 添加鋼でその固 溶強化の大きさに対応して疲労軟化することも, 一応説 明できる5

\section{$3 \cdot 2$ B シリーズ $(15 \mathrm{Cr}-15 \mathrm{Ni}$ 系) 鋼の低サイクル疲労 挙動に及ぼす $\mathrm{C}, \mathrm{Si}$ の影響}

オーステナイト系ステンレス鋼における Si 添加は, s.f.e. および C, N の活量に影響する. s.f.e.に及ぼす 影響についてみると, Si 添加によつて s.f.e.がかなり 低下することが多く報告されている15)20)．前述したよ うな IS 結合体が存在するとすれば，短範囲規則格子の 強化理論から，一度転位が IS 結合体の結合を切ると， 同じすべり面上を次の転位がすべるときの抵抗が小さく なることが類推される．そのため転位は平面状に配列し やすくなると考えられるが，s.f.e.が低ければ転位が同 一すべり面上をすべる確率がより高くなるので一層この 傾向が強まり，変形抵抗の低下（軟化）が促進されるよ うになるものと考察される。また $\mathrm{Si}$ は $\mathrm{C}, \mathrm{N}$ の活量を 増すとされている ${ }^{18)}$. したがつて，IS 結合体が形成さ れるとすると $\mathrm{Si}$ の添加によりその傾向が促進され, 強 度がそのぶん高くなり疲労軟化の割合も大きくなること が考えられる、いずれにしても, 疲労軟化あるいは転位 配列に及ほす C 添加の影響を検討する場合には，ステン レス鋼に通常含まれている $\mathrm{Si}$ の影響を無視することは できないものと予測される。しかし，この点を考慮した 研究は従来見られない.そこで $\mathrm{C}, \mathrm{Si}$ 無添加鋼（B-1） を基本鋼として, $\mathrm{Si}, \mathrm{C}$ 単独添加鋼（B-2， B-3）およ び複合添加鋼 $(\mathrm{B}-4)$ の度労挙動, 引張变形挙動, 転位 配列を比較, 検討した.
Fig. 2 全歪み振幅一定疲労試験結果の一例を示す. 全歪み振幅が $6.0 \times 10^{-3}$ あるいは $8.0 \times 10^{-3}$ と小さい 場合， C 単独添加鋼 (B-3), C, Si 複合添加鋼 $(B-4)$ で明暸な疲労軟化が見られるが，軟化の程度は B-4 鋼 のほうが大きい. 全歪み振幅が $1.2 \times 10^{-2}$ と大きくな ると B-4 鋼でのみ軟化が観察されるようになる. B-1,
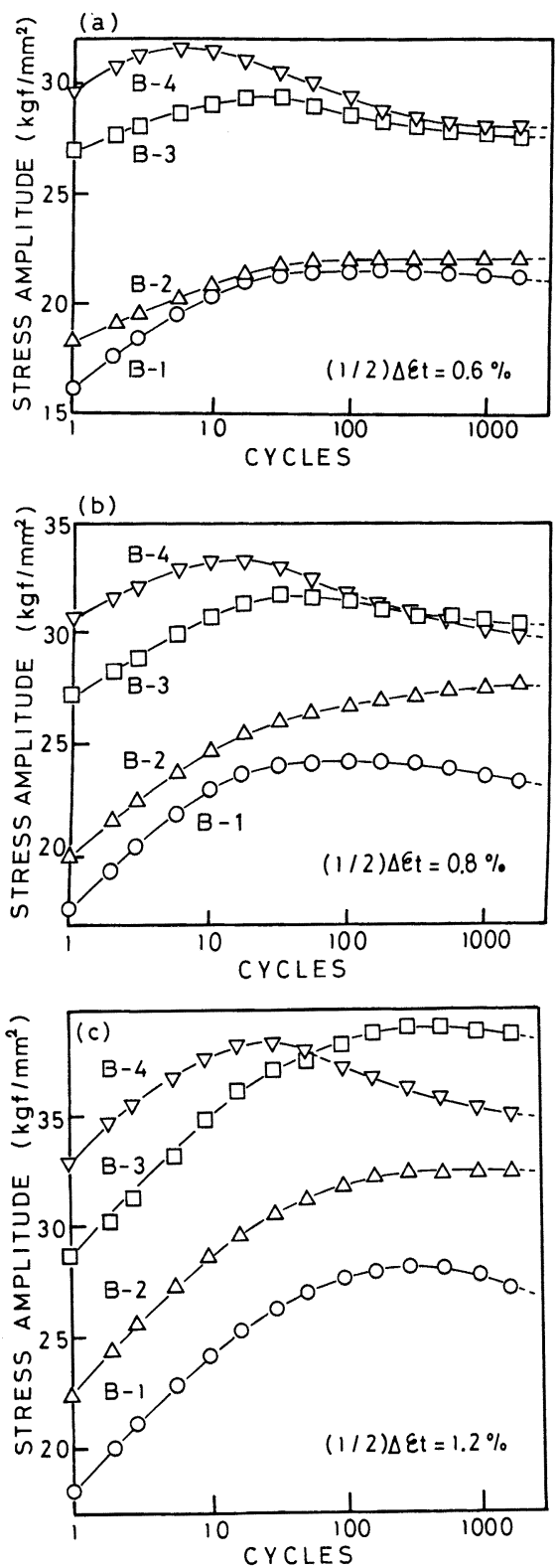

Fig. 2. Stress amplitude response in constant total strain amplitude tests of the B-series steels. The values of constant strain amplitude are (a) 6.0 $\times 10^{-3}$, (b) $8.0 \times 10^{-3}$ and (c) $1.2 \times 10^{-2}$. 
B-2 䤡（低 C，低 N）について見ると，Siを添加して いない B-1 鋼では, 高サイクル側でわずかの軟化が見 られる。この軟化は歪み振幅が大きくなるはど程度を増 す傾向にあることから，従来著者らが注目してきた軟化 と異なるものであると考えられる。この軟化の詳細につ いては現在検討中である. Si を添加した B-2 龬では軟 化は見られず，硬化が多くの繰返し数まで続く傾向にあ る. 一方, Fig. 2 は B-1〜B-4 鋼で強度水準が異なる ことも示している. そのため, 全歪み振幅一定試験では, これらの鎆の間で塑性是み振幅が異なつてしまう。そこ で, 塑性歪み振幅一定条件下での低サイクル疲労挙動も 調べた。結果を Fig. 3 に示す。この場合, 塑性歪み振 幅は $2.0 \times 10^{-3}$ とした，測定した繰返し数の範囲で， C無添加䤡では疲学軟化は観察されず，Cは単独添加で も疲労軟化を生じさせるが, Si と共存すると疲労軟化 の程度を大きくすることが分かる.

組穖観察結果の一例を Photo. 3 に示す.この場合繰 返し変形条件は, 全歪み振幅 $6.0 \times 10^{-3}$, サイクル数 100 回である. C, Si 無添加鋼（B-1）では，転位がセ ルを形成する傾向が強く，Si 単独添加鋼（B-2）の転 位は，B-1 龬と比べセル形成傾向が弱い，C単独添加 鋼（B-3）の転位は，B-2 鋼よりさらにセル形成傾向が
弱くなる。しかし，明暸な平面状転位組織は多くは見ら れない， C, Si 複合添加鋼（B-4）では，平面状の転位 組織が多く観察される.他の条件下で繰返し変形したも のについても，基本的に同様な傾向が観察された。

以上の観察結果をまとめてみると, (1)Cは単独添加で も疲労軟化を生じさせ，また転位のセル形成を妨げる方 向に働く, (2)Si の単独添加も転位の七ル形成の妨げる 方向に䡃くが, 疲労軟化は生じさせない, (3) Si は C と

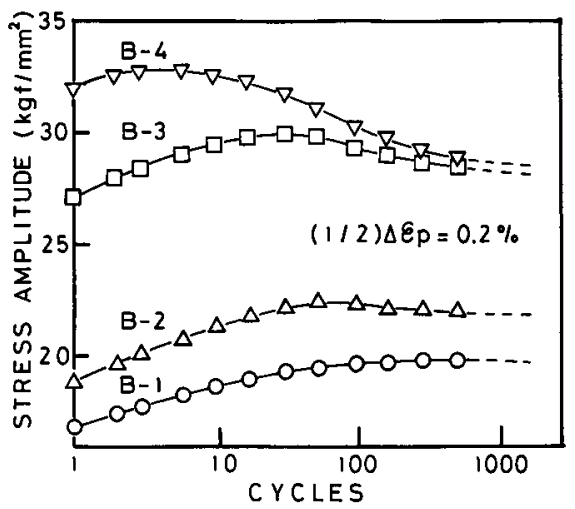

Fig. 3. Stress amplitude response in constant plastic strain amplitude tests of the B-series steels.

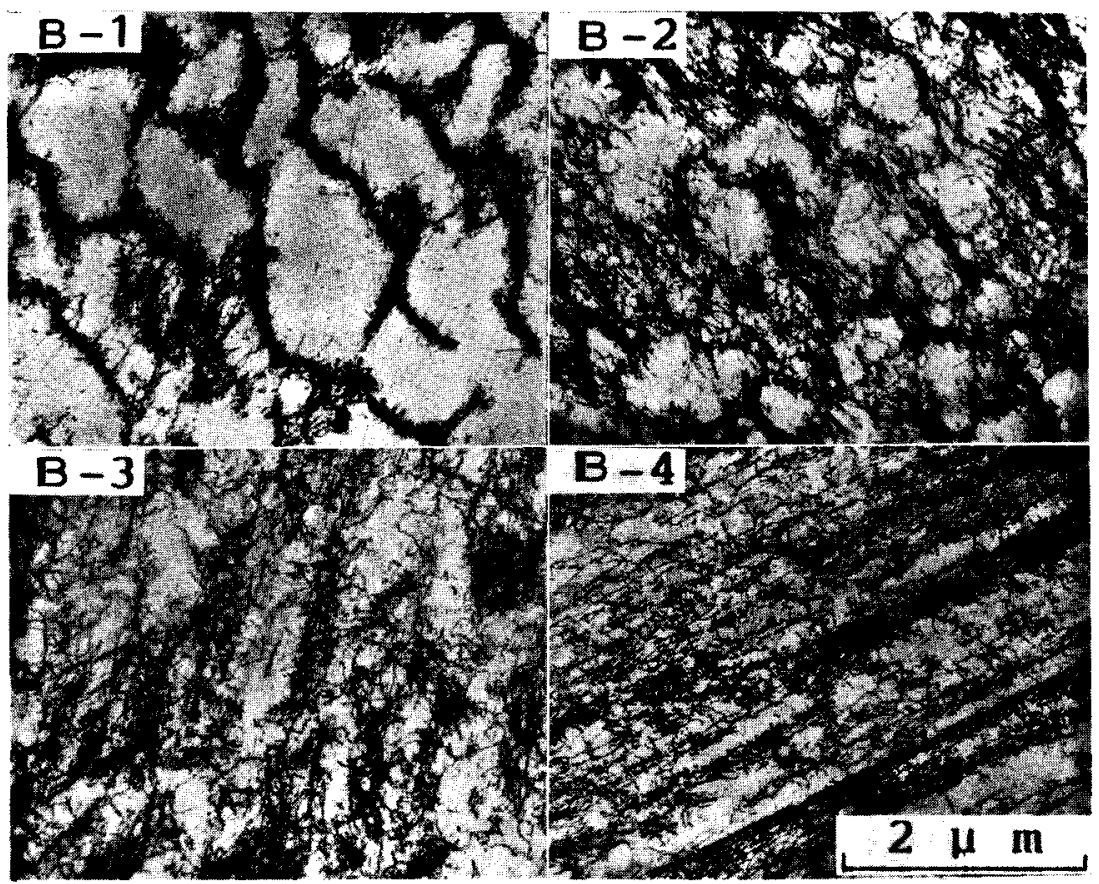

Photo. 3. Dislocation configurations of the B-series steels cyclically deformed for 100 cycles under $6.0 \times 10^{-3}$ total strain amplitude. 
複合添加すると疲労軟化の程度を増加させ，転位の平面 状配列を生じやすくする，(1)に関しては，IS 結合体の 存在を仮定することにより説明できることを，前節で述 べた，(2)に関しては，Si がs.f.e.を低下させることに より，セル形成が妨げられるものと考えられる。（3)に関 しては，本節の初めに述べたように，その原因が $\mathrm{Si}$ の s.f.e.に及ぼす効果とCの活量に及ぼす効果のいずれに よるのか明らかでないが， Si 添加の効果は IS 結合体 の存在を前提にした予測と一致する。そこで次に，Bシ リーズ鋼の引張変形時の強度および加工硬化挙動に及ぼ す $\mathrm{C}, \mathrm{Si}$ の影響を調べることによつて, IS 結合体の存 在に関する検討を行つた。

Fig. 4 は，Bシリーズ鋼の真応力-真歪み曲線 (a) と それらより求めた加工硬化率一真歪み曲線（b）である. 加工硬化率一真歪み曲線を見ると, B-1 鋼に比べ B-2 鋼 の加工硬化率が全体に大きい。これは，Siにより s.f. e. が低下するためと考えられる．B-1 鋼と B-3 鋼を比 較すると，B-2 鋼ほどではないが B-3 鋼の加工硬化率 のほうが大きい。この結果だけからみると，従来の報告 に反しCもs.f.e.を低下させることを示しているよう にも考えられる，B-3 鋼は疲労軟化を示すのに，本研
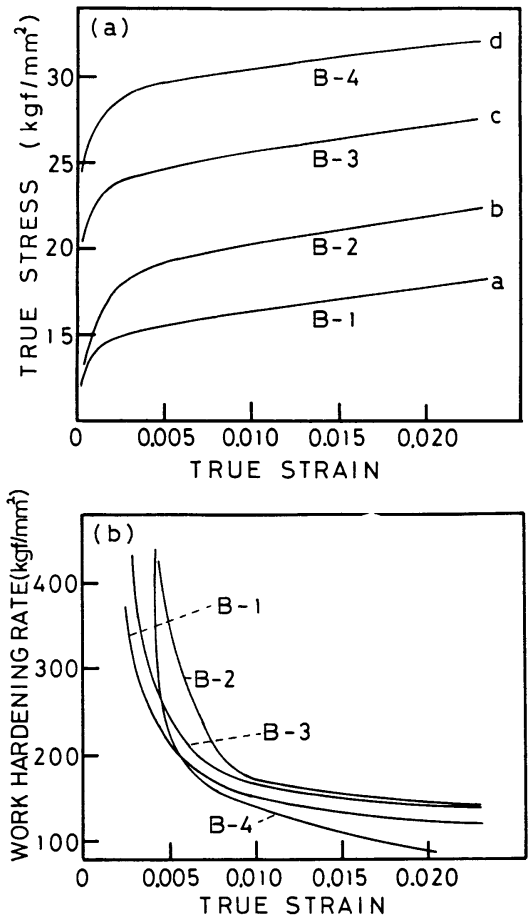

Fig. 4. (a) True stress-true strain and (b) work hardening rate-true strain curves of the $B$-series steels.
究で注目している疲労軟化を示さない B-1 鋼に比べ引 張変形時の加工硬化率が低下しないのは, 引張変形と繰 返し変形との相違によるものとも考えられる.しかし， s.f.e.に及ぼすCの影響とともに詳細は不明である. B-4 鋼の加工硬化率について見ると, 歪みの小さい範 囲では大きな值を示すようであるが，急速に減少し $0.4 \%$ 歪み程度から最も小さくなる。この結果は， $2 \%$ までの Si 添加は加工硬化に効かないとしている $\mathrm{SwANN}^{17)}$ の報告と一致しない。この不一致の原因は明 らかでないが, SwanN も指摘しているように, Si の効 果は $\mathrm{Cr}$ 量, $\mathrm{Ni}$ 量によって異なることによるとも考え られる。.また加工硬化率の急速な隇少は，この鋼が大き な疲労軟化を示すことと対応する可能性も考えられる. 次に，固溶強化と加工硬化率に及ぼす Cの影響を区別し て検討するため, Fig. 4 (a)より Fig. 5 を得た. Fig. 5 の曲線(1)，(2)，(3)は，おの扔の Fig. 4 の曲線 b と a , $\mathrm{c}$ と $\mathrm{a}, \mathrm{d}$ と a の差を，いくつかの真歪みにおいて読み とり真歪みの対数に対してプロットしたものである. 曲 線(4)は曲線(1)，(2)がおのおの強度に及ぼす $\mathrm{Si}, \mathrm{C}$ 単独添 加の効果を示すものと考え, B-1 鋼と B-4 鋼の強度差 を $\mathrm{Si}$ 量， $\mathrm{C}$ 量の相違のみから計算したものである。す なわち曲線(4)は $\mathrm{Si}$ と C に相互作用がない場合の，C, $\mathrm{Si}$ 複合添加の影響を近似的に示すものである。この際, 結晶粒径は B-1 鋼でおよそ $670 \mu \mathrm{m}, \mathrm{B}-2 \sim \mathrm{B}-4$ 鋼でお よそ $600 \mu \mathrm{m}$ であつたが，この程度の結晶粒径の相違は 強度にほとんど影響を及ぼさない21)として無視した。

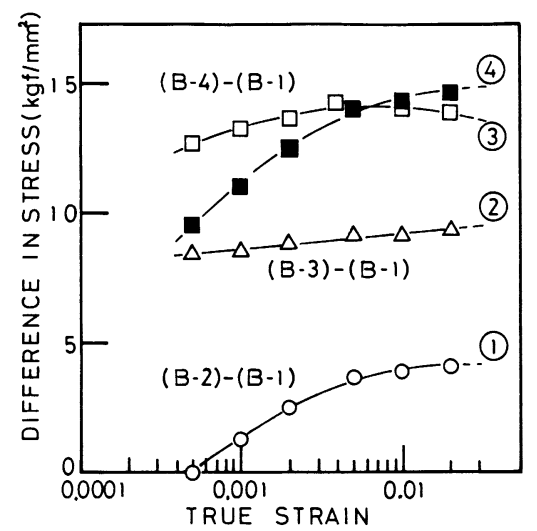

Curves (1), (2) and (3) show the difference in the strength of B-2, B-3 and B-4 from that of B-1 steel, respectively. They were obtained from the results exhibited in Fig. $4(\mathrm{a})$ and are showing approximately the effect of $\mathrm{Si}, \mathrm{C}$, and $\mathrm{Si}+\mathrm{C}$, respectively. Curve (4) shows approximately the strength difference between B-4 and B-1 steels when the cooperative effect between $\mathrm{Si}$ and $\mathrm{C}$ does not exist.

Fig. 5. Strain dependense of the increase in strength by $\mathrm{C}$ and $\mathrm{Si}$. 
これらの曲線は，強度に及ぼす固溶元素の影響は歪みを どこにとるかによつて異なることを示している，そのた め，純粋に固溶強化の大きさを比較する場合にはできる だけ小さな歪みのところで比較するのが妥当と考えられ る.いま $0.05 \%$ 真歪みにおいて強度に及ぼす C, Si の 影響をみると，Fig. 5 から，固溶強化に及ぼす Si の効 果はほとんど認められないこと, Cは単独でかなり大き な固溶強化作用を有すること, Cの固溶強化は $\mathrm{Si}$ が共 存するとさらに大きくなることが認められる. Si がC の固溶強化を増加させることは, ステンレス鋼の固溶強 化に関する従来の研究において見逃されていた点であ り, Fig. 5 の曲線(3)と(4)を比べると,このことは少な くとも $0.2 \%$ 耐力においてもいえることが分かる. 実 際に, 本研究で得られた Si 添加による $0.2 \%$ 酎力 ( 2 回測定した平均值）の増分を, オーステナイト系ステン レス鋼における固溶体強化に関してよく引用される IRVINE $ら^{22)}$, DYSON $5^{6)}$ の回㷌分析結果を用いて得た計 算值と比較すると, Cが共存しない場合, 実験值は計算 值のおよそ 2 分の 1 となり, Cが共存する場合は計算值 とほほ同じとなる。これは, IRVINE らや DYSON らが, Si と Cの効果をそれぞれ $\mathrm{C}, \mathrm{Si}$ との共存下で調べているこ とによるためと考えられる.

以上のように, 引張変形挙動の観祭より, Cによる強 化が Si 添加により増加することが明らかにされた．別 の見方をすれば，これはCによるおもな固溶強化が $\mathrm{Si}$ 添加により増加するような機構によつていることを示す ものと考えられるが, IS 結合体による強化が Si 添加 により増加する可能性のあることはすでに述べた。一方， Cによるおもな固溶強化機構は, また, 疲労軟化挙動, 変形材における転位の平面状組織への配列傾向の原因と なるものと考えられる ${ }^{4) 5)}$ ささらにその機構はNによる 機構と同様なものと考えられるが, Cの効果と $\mathrm{N}$ の効果 の大きさの相違をも説明できるものでなければならな (4)5).これらのことを総合すると，現在までのところ Cによるおもな固溶強化機構を IS 結合体によるものと するのが最も考えやすい.

\section{4. 結 論}

$20 \mathrm{Cr}-15 \mathrm{Ni}$ 系及び $15 \mathrm{Cr}-15 \mathrm{Ni}$ 系ステンレス鋼の低サ イクル疲労挙動に及ぼす C 添加の影響を調べ以下のよう な結論を得た。(1)すでに報告した $25 \mathrm{Cr}-20 \mathrm{Ni}$ 系鋼同様, C添加鋼は低サイクル疲労軟化を示す. (2)この疲労軟化 は，C量が多いほどまた繰返し歪み振幅が小さいほど程 度を増す。これは， N添加したステンレス鋼及び高マン ガン鋼における疲労軟化に及ぼす $\mathrm{N}$ 量と歪み振幅の効果
と同様である。(3)C添加は，繰返し変形材における転位 のセル形成を抑制し平面状組織形成を促進する傾向を有 する.これも，ステンレス鋼および高マンガン鋼におけ る $\mathrm{N}$ 添加の効果と同様である. (4) C 添加鋼の疲労軟化傾 向, 転位の七ル状組織形成抑制傾向は, Si 添加によつ て促進される. (5) Cによる固溶強化は Si が共存すると 一層大きくなることが明らかにされた. (6)以上の結果は, 溶体化処理状態で IS 結合体が存在し強化のおもな原因 となり, 疲労軟化はそれが繰返し変形によつて破壊され ることによつて生じると考える疲労軟化機構から推察さ れる結果と定性的に一致する.

終わりに，供試材の準備に御助力いただいた金属材料 技術研究所の中川龍一所長, 河部義邦部長, 高橋順一氏, 工業化研究部の方々，及び単結晶を作成していただいた 日新製鋼(株)の星野和夫課長，武本敏夫氏に深謝致しま す.また研究費の一部は文部省科学研究費補助金（一般 研究C, 昭和 60,61 年度) によつたことを付記します。

\section{文献}

1) R. P. ReEd and N.J. Simon: Advances in Cryogenic Engineering Materials, 30 (1984), p. 127

2 ) $K$. Shibata, $Y$. Kishimoto, $N$. Namura and $T$. Fujita : Fatigue at Low Temperature (ASTM STP 857) (1985), p. 31 [ASTM]

3 ) 柴田浩司, 名村夏樹, 岸本康夫, 藤田利夫: 鉄と鋼, 69 (1983), p. 2076

4 ) 柴田浩司, 岸本康夫, 藤田利夫: 鉄と鋼, 71 (1985), p. 1795

5 ）柴田浩司，藤田利大: 鉄と鋼，73 (1987), p. 1178

6 ) D. J. Dyson and B. HolmEs: J. Iron Steel Inst., 208 (1970), p. 401

7 ）加藤哲男，藤倉正国，矢萩慎一郎，石田清仁: 鉄と鋼，67 (1981), p. 587

8 ）木下凱雄, 竹田誠一: 日本金属学会会報, 18 (1979), p. 642

9 ）昆 謙造: 防食技術, 32 (1983), p. 593

10) H. J. Kestenbach: Phil. Mag., 36 (1977), p. 1509

11) P. J. Brofman and G. S. AnsCLL: Metall. Trans. A, 9 (1978), p. 879

12) R. Fawley, M. A. Quader and R. A. Dodd: Trans. AIME, 242 (1968), p. 771

13) R. E. Stolyz and J. B. V. Stande: Metall. Trans. A, 11 (1980), p. 1033

14）吉田博行: 日本金属学会会報, 13 (1973), p. 873

15) C. G. Rhodes and A. W. Thompson: Metall. Trans. A, 8 (1977), p. 1901

16) H. Suzuki: Strength and Metals and Alloys, vol. l, ed. by R. C. Gifkins (1982), p. 327 [Pergamon Press]

17) P. R. Swann: Corrosion, 19 (1963), p. 102

18）西沢泰二: 日本金属学会会報, 12 (1972), p. 401

19) D. L. Douglass, G. Thomas and W. R. Roser: Corrosion, 20 (1964), p. 15

20) R. E. Schramm and R. P. ReED: Metall. Trans. A, 6 (1975), p. 1345

21）藤倉正国，加藤哲雄: 鉄と鋼， 64 (1978), p. 2195

22) $K$. J. IRvine, T. Gladman and $F$. B. Pickering: J. Iron Steel Inst., 207 (1969), p. 1017 